\title{
Regulation of Rat Luteinizing Hormone Subunit Messenger Ribonucleic Acids by Gonadal Steroid Hormones
}

Soheyla D. Gharib, Stephen M. Bowers, Laura R. Need, and William W. Chin

Section on Molecular Genetics, Joslin Diabetes Center and Howard Hughes Medical Institute Laboratories, Harvard Medical School, Boston, Massachusetts 02215

\begin{abstract}
Little is known about the hormonal regulation of luteinizing hormone (LH) biosynthesis. We have studied the regulation of $\mathrm{LH}$ messenger RNA (mRNA) levels by gonadal-steroid hormones in the rat. In one set of experiments, male and female rats were surgically gonadectomized (GDX) and killed 1, 3, 7, 14, 22, and 31 d postoperatively. In another set of experiments, male and female rats were surgically GDX and were injected subcutaneously with testosterone propionate $(500 \mu \mathrm{g} / 100 \mathrm{~g}$ body wt per d) or $17 \beta$-estradiol 3-benzoate $(10 \mu \mathrm{g} / 100 \mathrm{~g}$ body wt per d), respectively, beginning 3 wk postoperatively. Levels of serum LH were determined by radioimmunoassay and levels of $\mathrm{LH}$ subunit mRNAs in single pituitary glands were determined by blot hybridization analysis using labeled synthetic oligodeoxyribonucleotide probes that correspond to portions of the coding regions of the rat $\alpha$ - and $L H \beta$-subunit mRNAs. 4 wk after gonadectomy, serum LH levels rose nine- and 20 -fold, while $\alpha$-subunit mRNA levels rose six- and 10 -fold, and $\mathrm{LH} \beta$-subunit levels rose seven- and 14-fold, compared with controls in males and females, respectively. In gonadal-steroid hormone-treated male and female GDX rats, serum LH levels fell to 8 and $36 \%$ of control values, while $\alpha$-subunit mRNA levels declined to 22 and $19 \%$, and $L H \beta$-subunit mRNA levels declined to 6 and $10 \%$ of control values, $48 \mathrm{~h}$ after injections were initiated, in males and females, respectively. We conclude that gonadal-steroid hormones negatively regulate the levels of both subunit mRNAs in GDX rats in a pattern that parallels the changes in serum $\mathbf{L H}$ values. These data suggest that gonadal-steroid hormone regulation of $\mathrm{LH}$ biosynthesis occurs, at least in part, at the level of LH subunit mRNAs due to effects at the transcriptional and/or RNA stability levels.
\end{abstract}

\section{Introduction}

Luteinizing hormone (lutropin, $\mathrm{LH})^{1}$ is essential for normal sexual development and function, and stimulates a variety of re-

Address correspondence to Dr. Gharib, Biosciences Research Building, Room 917, Brigham and Women's Hospital, 75 Francis St., Boston, MA 02115.

Received for publication 28 November 1984 and in revised form 3 September 1985.

1. Abbreviations used in this paper: ADU, arbitrary densitometric units: CAST, orchiectomy (castration); cDNA, complementary DNA; GDX, gonadectomized; LH, luteinizing hormone; mRNAs, messenger RNAs; OVX, ovariectomy; rLH, rat LH; SSC, $0.15 \mathrm{M} \mathrm{NaCl} / 0.015 \mathrm{M}$ sodium citrate, $\mathrm{pH} 7$.

J. Clin. Invest.

(c) The American Society for Clinical Investigation, Inc.

0021-9738/86/02/0582/08 \$1.00

Volume 77, February 1986, 582-589 productive processes including gametogenesis and production of gonadal-steroid hormones. It is a glycoprotein hormone produced in the anterior pituitary gland, and consists of the two noncovalently bound subunits, $\alpha$ and $\operatorname{LH} \beta$ (1), which are encoded by separate genes $(2-5)$. $\mathrm{LH}$ is structurally related to the other pituitary glycoprotein hormones, follicle-stimulating hormone and thyroid-stimulating hormone, as well as the placental glycoprotein hormone, chorionic gonadotropin. Each of these glycoprotein hormones, within a species, consists of a nearly identical $\alpha$-subunit and a unique $\beta$-subunit that dictates the biologic specificity of the hormone (1).

Although it is well known that gonadal steroid hormones regulate the serum levels and pituitary content of LH (6-13), little is known about their regulation of the biosynthesis of the subunits of $\mathrm{LH}$ at the transcriptional and the posttranscriptional levels. The excess production of $\alpha$-subunits over LH $\beta$-subunits $(14,15)$ has suggested that the rate of $\mathrm{LH} \beta$-subunit synthesis determines the amount of intact LH produced (16-19). Several studies at the pretranslational level using cell-free translational analyses have indicated that the levels of $\alpha$ - and $\mathrm{LH} \beta$-subunit messenger RNAs (mRNAs) are elevated in castrate animals (1720 ), and that they decrease with gonadal steroid replacement (7, $9,21)$. In a detailed study examining the time course of the gonadectomy-induced increase in translatable $\alpha, \mathrm{LH} \beta$, and follicle stimulating hormone- $\beta$ precursors, Corbani et al. (20) found that maximum levels of subunit precursors were reached $\sim 3$ wk after castration, but that significant increases were noted as early as $1 \mathrm{wk}$ after castration. While these studies provide an indirect measurement of subunit mRNA levels, they are limited by the possibility that these results might also be explained by changes in translational efficiency.

More recently, steady state levels of pituitary LH subunit mRNAs, quantitated directly by blot hybridization analyses, have been shown to increase in castrate ewes and to decline with estradiol treatment (8). In addition, Tepper et al. (22), in a preliminary report, have showed that $\mathrm{LH} \beta$-subunit mRNA levels, measured from pooled ovariectomized rat pituitary glands, using dot-blot hybridization techniques, rise fourfold above control levels in $4 \mathrm{wk}$, and that these levels return to nearly normal values after $3 \mathrm{~d}$ of estradiol treatment.

The aim of this study is to examine the changes in the steady state levels of mRNAs encoded by $\alpha$ - and LH $\beta$-subunit genes in two physiologic models: ( $a$ ) gonadectomized (GDX) rats and (b) GDX rats treated with gonadal-steroid hormones. Our results indicate that LH subunit mRNA levels are indeed regulated by gonadal-steroid hormones and hence, that regulation of $\mathrm{LH}$ biosynthesis by these hormones occurs, at least in part, at the pretranslational level. We have examined these changes at multiple time points using a technique to measure subunit mRNA levels in individual rat pituitary glands, which allows a statistical analysis of these data. 


\section{Methods}

Experimental protocols. We used male and female Sprague-Dawley rats (CD strain; 175-200 g and 200-225 g; Charles River Breeding Laboratories, Wilmington, MA) in all experiments. Male and female rats were surgically GDX by orchiectomy (castration; CAST) and ovariectomy (OVX), respectively. The GDX animals were divided into two groups. In the first group, animals were killed by decapitation 1, 3, 7, 14, 22, and $31 \mathrm{~d}$ after CAST or OVX. In the second group, GDX animals (3 wk postoperative) were then injected subcutaneously with testosterone propionate (males, $500 \mu \mathrm{g} / 100 \mathrm{~g}$ body wt per d) or $17-\beta$-estradiol-3benzoate (females, $10 \mu \mathrm{g} / 100 \mathrm{~g}$ body wt per $\mathrm{d}$ ) in sesame oil. Animals were sacrificed by decapitation $0,12,24,48 \mathrm{~h}$, and $7 \mathrm{~d}$ after injections were initiated. Trunk blood was obtained from all animals for determination of serum LH. Pituitary glands were removed by careful dissection, quick-frozen, and stored in liquid nitrogen.

Radioimmunoassay (RIA) of $L H$. Serum levels of rat $\mathrm{LH}(\mathrm{rLH})$ were determined by RIA using National Institute of Arthritis, Metabolism, and Digestive Diseases (NIAMDD) reagents as described previously (23) except that they have been calculated from a standard curve employing the highly purified NIAMDD-rLH. The use of highly purified iodinationgrade hormones for standards has been described (24). This preparation is $\sim 61$ times more potent than the previously supplied reference preparation (RP-1), and is similar in potency to the currently supplied reference preparation (RP-2), according to information supplied with the hormone. As a result, the values for serum LH presented in this paper are lower than those observed by other investigators who have used RP1 , or other less pure reagents $(13,25)$. For example, our mean values $\pm S D$ for normal males, $1.1 \pm 0.49 \mathrm{ng} / \mathrm{ml}$, and for normal females, $0.33 \pm 0.34$

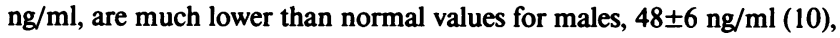
and females, $110 \pm 50 \mathrm{ng} / \mathrm{ml}$ (13), previously reported.

Synthetic labeled oligodeoxyribonucleotides. Oligodeoxyribonucleotides (probes) complimentary to the rLH subunit RNAs and corresponding to portions of the coding regions of the rat $\alpha$-subunit ( 21 nucleotides including amino acids +33 to +40$)(26)$ and rat LH $\beta$-subunit (17 nucleotides including amino acids +31 to +36$)(27)$ were synthesized on an automated DNA synthesizer (Applied Biosystems, Inc., Foster City, CA). The probes were 5 -end-labeled using $\left[\gamma-{ }^{32} \mathrm{P}\right] A T P(7,000 \mathrm{Ci} / \mathrm{mmol})$ (New England Nuclear, Boston, MA) and polynucleotide kinase (New England BioLabs, Beverly, MA) to achieve a specific activity of 6-7 $\times 10^{6} \mathrm{cpm} / \mathrm{pmol}$ DNA (28).

Nick translation. A complementary DNA (cDNA) encoding $\beta$-actin derived from mouse 3T3 cells (courtesy of Dr. Bruce M. Speigelman) was used to normalize the amount of total RNA added to the agarose gels from each pituitary (see below). The probe was nick-translated using $\left[\alpha-{ }^{32} \mathrm{P}\right] \mathrm{dCTP}(>3,000 \mathrm{Ci} / \mathrm{mmol})$ (New England Nuclear), Escherichia coli DNA polymerase I (Boehringer Mannheim Diagnostics, Inc., Houston, TX), and deoxyribonuclease I (Cooper Biomedical, Inc., Malvern, PA) to achieve a specific activity of $1-2 \times 10^{8} \mathrm{cpm} / \mu \mathrm{g}$ DNA (29).

LH subunit $m R N A$ determinations. Total RNA was extracted from individual rat pituitaries and levels of LH subunit mRNAs were determined using blot hybridization analysis. The method used for total RNA extraction has been previously described by Chirgwin et al. (30), but was modified to allow isolation of RNA from individual rat pituitaries. Each pituitary was homogenized in $4 \mathrm{M}$ guanidinium thiocyanate by sonication (Sonifier Cell Disruptor Model 200; Branson Sonic Power Co., Danbury, CT). The sonicates were then layered over $5.7 \mathrm{M} \mathrm{CsCl}$ and spun at $100,000 \mathrm{~g}$ in an air-driven centrifuge (Airfuge; Beckman Instruments, Inc., Spinco Div., Palo Alto, CA) for $16 \mathrm{~h}$ at $4^{\circ} \mathrm{C}$. The RNA pellets were dissolved in sterile distilled water and the RNA was ethanol-precipitated. From each pituitary, 3-5 $\mu \mathrm{g}$ RNA $\left(\mathrm{OD}_{260}\right)$ was denatured with glyoxal and dimethylsulfoxide, subjected to electrophoresis on a $1.4 \%(\mathrm{wt} / \mathrm{vol})$ agarose gel, and transferred to nitrocellulose paper by diffusion blotting (31).

The blots were then baked at $90^{\circ} \mathrm{C}$ for $2 \mathrm{~h}$ and rinsed with $20 \mathrm{mM}$ Tris- $\mathrm{HCl}, \mathrm{pH} 8$, at $90^{\circ} \mathrm{C}$ for $10 \mathrm{~min}$ to inactivate glyoxal. The blots were hybridized with 5'-end-labeled, synthetic, oligodeoxyribonucleotide probes (described above) and hybridization buffer (32). Hybridization buffer used for the 5'-end-labeled, synthetic oligonucleotide probes, $\alpha$ and $\mathrm{LH} \beta$, consisted of $6 \times \operatorname{SSC}(1 \times \mathrm{SSC}=0.15 \mathrm{M} \mathrm{NaCl} / 0.015 \mathrm{M}$ sodium citrate, $\mathrm{pH} 7), 5 \times$ Denhardt's solution $(1 \times$ Denhardt's $=0.02 \%$ [wt $/ \mathrm{vol}]$ Ficoll-400, 0.02\% [wt/vol] bovine serum albumin, $0.02 \%$ [wt/vol] polyvinylpyrrolidine-40), $100 \mu \mathrm{g} / \mathrm{ml}$ sonicated, denatured salmon sperm DNA, and $0.5 \%$ [wt/vol] sodium dodecyl sulfate [SDS]) (32). The hybridization buffer used for hybridization with the nick-translated $\beta$-actin cDNA probe consisted of $40 \%$ (vol/wt) formamide, $4 \times$ SSC, $7 \mathrm{mM}$ Tris$\mathrm{HCl}, 1 \times$ Denhardt's solution, $2 \mu \mathrm{g} / \mathrm{ml}$ sonicated, denatured salmon sperm DNA, and $10 \%(\mathrm{wt} / \mathrm{vol})$ dextran sulfate.

Three successive hybridizations were performed with three different labeled probes (described above): $\alpha, \operatorname{LH} \beta$, and $\beta$-actin. Hybridizations were allowed to occur over $16 \mathrm{~h}$ at the appropriate temperature $\left(55^{\circ} \mathrm{C}\right.$ for the $\alpha$-subunit, $50^{\circ} \mathrm{C}$ for the $\mathrm{LH} \beta$ subunit, and $42^{\circ} \mathrm{C}$ for the nicktranslated $\beta$-actin cDNA probe). After the hybridizations with the synthetic, oligodeoxynucleotide probes, $\alpha$ and $\mathrm{LH} \beta$, the blots were washed in $6 \times \mathrm{SSC}, 0.1 \% \mathrm{SDS}$ at $55^{\circ} \mathrm{C}$ ( $\alpha$-subunit DNA probe) or $50^{\circ} \mathrm{C}(\mathrm{LH} \beta-$ subunit DNA probe) to remove unhybridized probes. After hybridization with the nick-translated $\beta$-actin cDNA probe blots were washed in $2 \times$ SSC, $0.1 \%$ SDS at $42^{\circ} \mathrm{C}$ to remove the unhybridized probe. The blots were then subjected to autoradiography at $-70^{\circ} \mathrm{C}$ with an intensifying screen. Band intensities were determined by semiquantitative analysis by scanning densitometry. Between hybridizations, blots were incubated in $20 \mathrm{mM}$ Tris- $\mathrm{HCl}\left(\mathrm{pH} 8\right.$ ) at $90^{\circ} \mathrm{C}$ for $10 \mathrm{~min}$ to remove the hybridized probe and to prepare for the next hybridization. Dose-response curves, with dilutions of RNA ranging from 0.625 to $10 \mu \mathrm{g}$, were linear with correlation coefficients of 0.99 to 1.00 . RNA recovery was assessed to be $>90 \%$.

Standardization of data. Since variation in amounts of total RNA from each pituitary applied to the gels exists, it was necessary to develop a method of internal standardization. We accomplished this by hybridizing the same Northern blots used in the subunit mRNA studies with a nick-translated $\mathrm{CDNA} \beta$-actin probe as described above. The densities of the bands on the autoradiograms were then determined by scanning densitometry. The density of the bands on the $\beta$-actin Northern blots was assumed to be proportional to the amount of total pituitary RNA that had been applied to the gel. The density of each band on the $\beta$-actin Northern blot was expressed as a ratio of an arbitrarily selected band on the same blot, and this ratio was then used to calculate corrected values for the densities of the corresponding bands on the $\alpha$ - and LH $\beta$-probed Northern blots. By this method, we were able to provide internal standardization for the amounts of subunit mRNAs represented by each autoradiographic band. $\beta$-actin is an essential structural protein required for cellular integrity and its concentration within the cell is not known to change with treatment with gonadal steroids. $\beta$-actin has been used in other studies as an internal mRNA control (33). Furthermore, the densities of the bands on the $\beta$-actin-probed blots did not change with time after gonadal-steroid treatment (data not shown).

Statistical analysis. All RIA data were subjected to Tukey's $t$ test (34). The scanning densitometry data from the gonadectomy experiments were fitted to a linear regression model that correlated the quantity of RNA against time after castration (34). The Kendall correlation test (35) and the Wilcoxon rank sum test (Mann-Whitney variation) (35) were used to analyze the experiments in which GDX rats were treated with gonadal-steroid hormones.

\section{Results}

Our general approach was to evaluate the time-related changes in serum LH and pituitary LH subunit mRNA levels in (a) GDX and $(b)$ gonadal-steroid hormone-treated GDX male and female rats.

\section{Gonadectomy}

Males. The serum LH levels, determined by RIA, increased markedly with time in CAST rats. Mean serum LH levels increased from $1.10 \pm 0.4 \mathrm{ng} / \mathrm{ml}$ in control animals to $6.74 \pm 1.20$ 

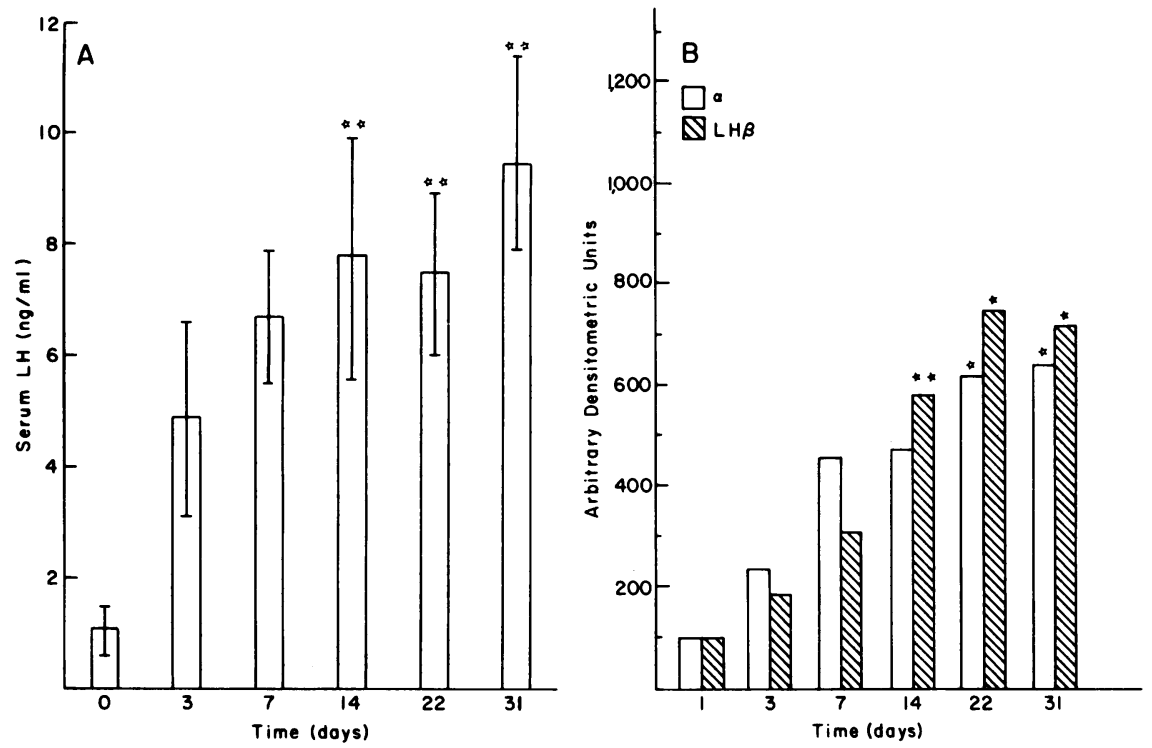

Figure 1. Serum LH and pituitary LH subunit mRNA levels. CAST: $(A)$ Serum LH levels of male rats at various time points after castration were measured by RIA. Each bar represents the mean \pm SD of serum LH for 4-7 rats. $(B)$ The steady state levels of $\alpha$-subunit and LH $\beta$-subunit mRNAs in pituitaries of male rats were measured at various time points after castration. The optical density of each band from the autoradiograms of the RNA blots shown in Fig. 2 was measured with a scanning densitometer. Each bar represents the mean density of two bands for each time point. The open bars correspond to the bands shown in Fig. $2 A$, which represent RNAs hybridized to the $\alpha$-subunit DNA probe. The shaded bars correspond to the bands shown in Fig. $2 B$, which hybridized to the $\mathrm{LH} \beta$-subunit DNA probe. Stars indicate statistical significance of data points compared to control levels: *, $P<0.05$; and **, $P<0.01$.

$\mathrm{ng} / \mathrm{ml}(P<0.001)$ by $22 \mathrm{~d}$ post-CAST, and to $9.40 \pm 2.05 \mathrm{ng} /$ $\mathrm{ml}(P<0.01)$ by $31 \mathrm{~d}$ post-CAST; these values represent sixand ninefold increases, respectively (Fig. $1 A$ ).

The LH subunit mRNA levels were determined by blot hybridization and semi-quantitative scanning densitometry of $x$ ray bands in autoradiograms. The LH subunit mRNA levels increased gradually with time (Fig. 2). The mean $\alpha$-subunit mRNA levels reached peak levels, $624 \pm 84$ arbitrary densitometric units (ADU), $22 \mathrm{~d}$ after CAST, which represented a 6.2-

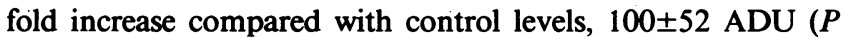
$<0.05)$. The $\mathrm{LH} \beta$-subunit mRNA levels reached peak levels 22 d after CAST, 747 \pm 183 ADU, a 7.5-fold elevation $(P<0.05)$ compared with control levels, 100 \pm 4 ADU (Fig. $1 B$ ).

These data were also subjected to simple linear regression analysis in which pituitary subunit mRNA concentration was regressed against time after GDX. The rises in $\alpha$-subunit mRNA levels $(P<0.001)$ and LH $\beta$-subunit mRNA levels $(P<0.01)$ in GDX males were found to be significant.

Females. The rise in mean serum $\mathrm{LH}$ in OVX rats also occurred gradually with time. Mean serum LH levels increased from $0.33 \pm 0.30 \mathrm{ng} / \mathrm{ml}$ in control animals to $3.51 \pm 0.21 \mathrm{ng} / \mathrm{ml}$ by $7 \mathrm{~d}(P<0.01)$ and to $8.61 \pm 0.53 \mathrm{ng} / \mathrm{ml}(P<0.01)$ by $31 \mathrm{~d}$ after CAST (Fig. $3 A$ ); these values represent 10- and 20-fold elevations, respectively.

The increases in LH subunit mRNA levels in OVX rats were more pronounced than those seen in the CAST rats (autoradiograms not shown). The mean $\alpha$-subunit mRNA levels rose from control levels of $100 \pm 42$ ADU to $184 \pm 17$ ADU by $7 \mathrm{~d}(P$ $<0.05)$ and to $878 \pm 312$ ADU by $22 \mathrm{~d}$ post-OVX $(P<0.01)$; these values represent 1.8 - and ninefold increases, respectively.

A

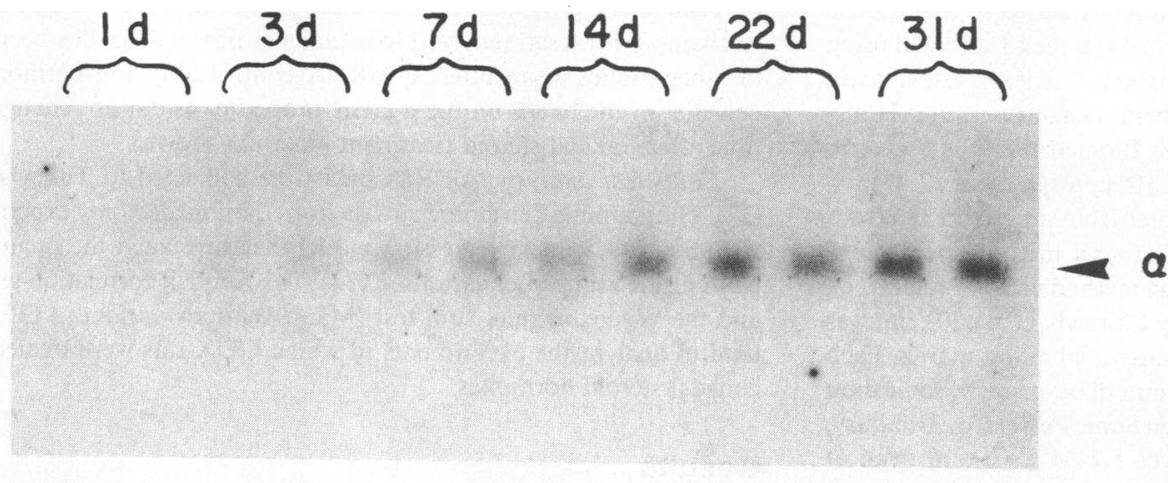

B

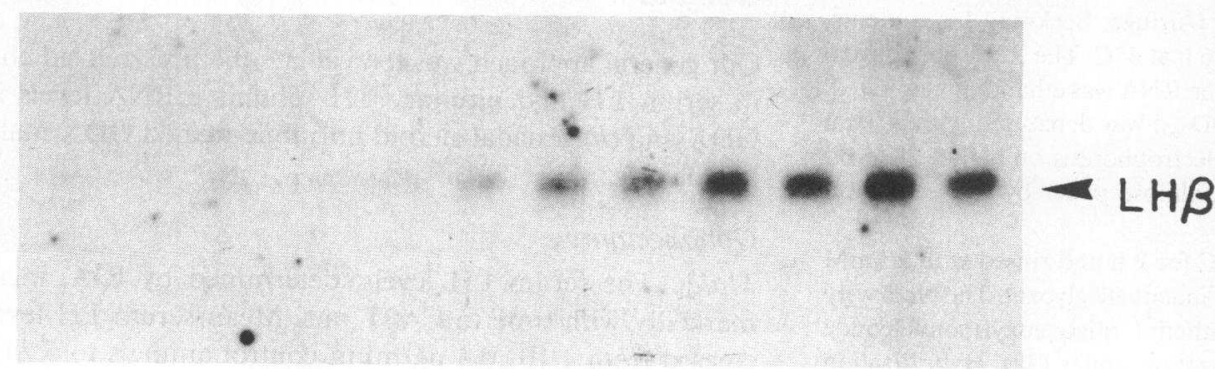

Figure 2. RNA blot hybridization analysis. CAST: Synthetic oligodeoxyribonucleotide probes corresponding to cDNAs specific for rat $(A) \alpha$-subunits and $(B)$ $\mathrm{LH} \beta$-subunits were hybridized to total cellular RNA from rat pituitary glands at various time points after castration as described in Methods. Each lane contains 3 $\mu \mathrm{g}$ of RNA from a single pituitary gland. The same blot was used for both hybridizations. Film exposure time was $24 \mathrm{~h}$ for $A$ and $90 \mathrm{~h}$ for $B$ using XAR film (Eastman Kodak Co., Rochester, $\mathrm{NY}$ ) and an intensification screen at $-70^{\circ} \mathrm{C}$. 

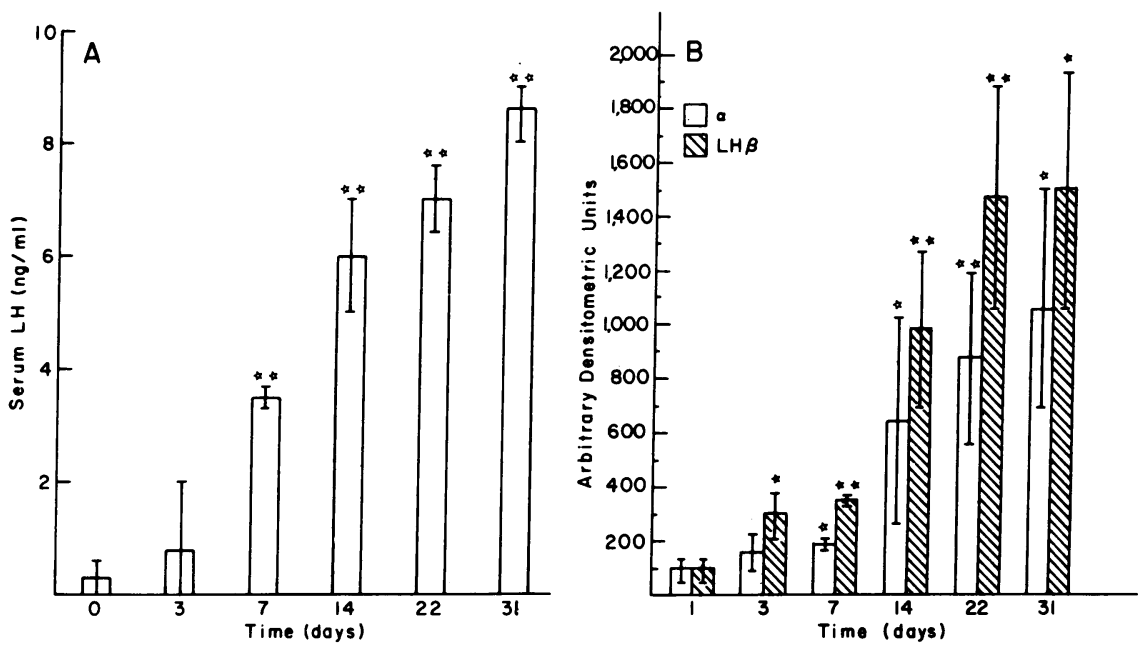

Figure 3. Pituitary LH subunit mRNA levels and serum LH levels. OVX: $(A)$ Quantitation of serum $\mathrm{LH}$ of female rats at various time points after OVX. Each bar represents the mean \pm SD of serum LH levels for three to five rats. (B) Levels of $\alpha$-subunit and $\mathrm{LH} \beta$-subunit mRNAs in pituitaries of female rats were measured at various time points after OVX. Autoradiograms of the RNA blots (not shown) were analyzed by scanning densitometry (see legend of Fig. 1). Each bar represents the mean density \pm SD of three bands for each time point. Open bars correspond to bands representing RNAs hybridized to the $\alpha$-subunit DNA probe. Shaded bars correspond to bands representing RNAs hybridized to the $\mathrm{LH} \beta$-subunit DNA probe. Stars indicate statistical significance of data points compared with control levels: $*, P$ $<0.05$; and **, $P<0.01$.

The rise in $\mathrm{LH} \beta$-subunit pituitary mRNA levels occurred earlier than that of the $\alpha$-subunit. LH $\beta$-subunit mRNA levels rose from the mean control level of $100 \pm 21$ to $307 \pm 84 \mathrm{ADU}$, $3 \mathrm{~d}$ post-OVX, a threefold increase $(P<0.05)$, and to $1,471 \pm 405$ ADU 22 d post-OVX $(P<0.005)$, a 15 -fold increase (Fig. $3 B$ ). Statistically significant trends were also seen in OVX rats for both $\alpha-(P<0.001)$ and LH $\beta$-subunit mRNA levels when these data were analyzed by simple linear regression $(P<0.0001)$. The rise in $\mathrm{LH} \beta$-subunit mRNA levels roughly paralleled the rise in serum levels.

\section{Gonadal-steroid treatment of GDX rats}

Males. Serum LH levels in CAST rats declined rapidly with testosterone treatment (Fig. $4 \mathrm{~A}$ ). They declined from control levels of $16.28 \pm 2.55 \mathrm{ng} / \mathrm{ml}$ to $4.86 \pm 0.77 \mathrm{ng} / \mathrm{ml}$ or $30 \%$ of control levels at $12 \mathrm{~h}(P<0.01)$, to $2.22 \pm 1.22 \mathrm{ng} / \mathrm{ml}$ or $14 \%$ of control levels at $24 \mathrm{~h}(P<0.01)$, to $1.36 \pm 0.44 \mathrm{ng} / \mathrm{ml}$ or $8 \%$ control levels at $48 \mathrm{~h}(P<0.01)$, and to $0.13 \pm 0.12 \mathrm{ng} / \mathrm{ml}$ or $0.8 \%$ of control levels $(P<0.01)$ at $7 \mathrm{~d}$ after injections were initiated.
The pituitary LH subunit mRNA levels in testosteronetreated CAST rats also declined significantly within $48 \mathrm{~h}$ (Fig. 5). The mean $\alpha$-subunit mRNA level decreased from $100 \pm 10$ ADU to $22.0 \pm 16.0$ ADU, or $22 \%$ of control levels at $48 \mathrm{~h}(P$ $<0.05$ ) and to $12.0 \pm 5.0 \mathrm{ADU}$, or $12 \%$ of control levels at $7 \mathrm{~d}$ $(P<0.05)\left(\mathrm{t}_{1 / 2}=24 \mathrm{~h}\right)$. The decline in LH $\beta$-subunit mRNA levels occurred more rapidly and paralleled the decline observed in serum $\mathrm{LH}$ levels. The mean $\mathrm{LH} \beta$-subunit mRNA level decreased from $100 \pm 35.0$ to $6.0 \pm 3.0 \mathrm{ADU}$, or $6 \%$ of control levels at $48 \mathrm{~h}(P<0.05)$, and to $1.9 \pm 0.9 \mathrm{ADU}$, or $2 \%$ of control levels at $7 \mathrm{~d}(P<0.05)$ after injections were initiated $\left(\mathrm{t}_{1 / 2}=9 \mathrm{~h}\right)$ (Fig. $4 \mathrm{~B}$ ).

The ratio of pituitary $\alpha$ - to $\mathrm{LH} \beta$-subunit mRNA levels increased with time after initiation of testosterone treatment in the GDX male rats. Note that subunit mRNA levels are expressed in arbitrary densitometric units. Because the hybridization probes did not possess identical specific activities, and exposure times of the two blots were different, comparisons of absolute amounts of $\alpha$ - and LH $\beta$-subunit mRNA levels cannot
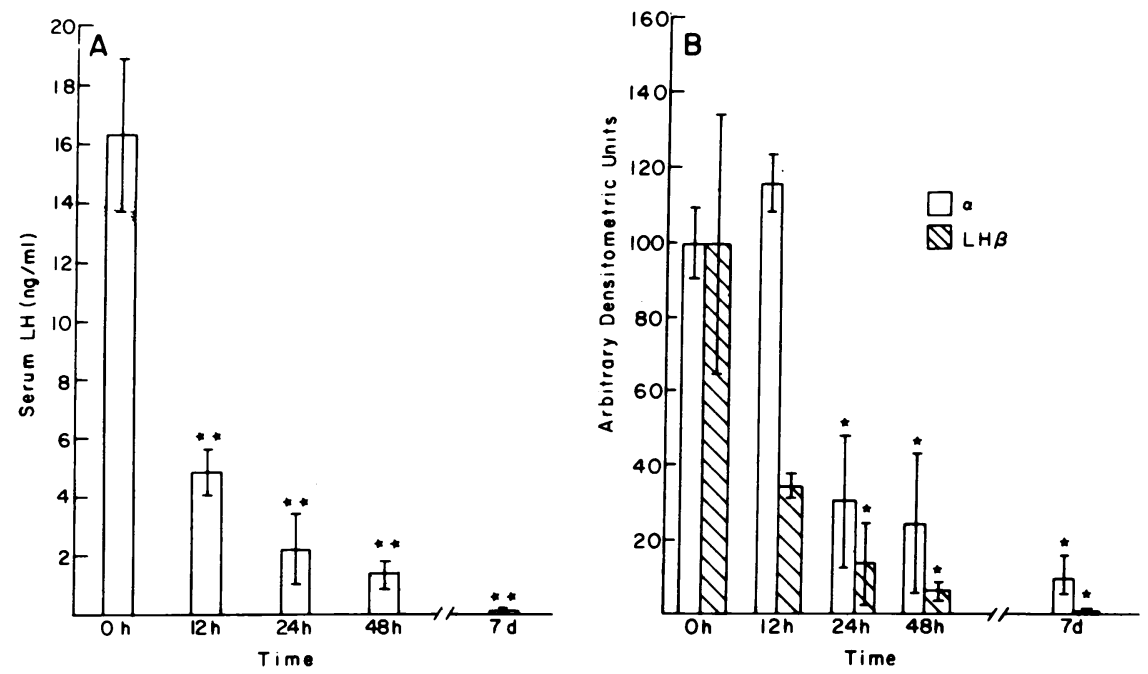

Figure 4. Serum LH levels and pituitary LH subunit mRNA levels. Testosterone-treated CAST rats. $(A)$ Serum LH levels of CAST rats were measured at different time points after treatment with testosterone propionate. Each bar represents the mean \pm SD serum $\mathrm{LH}$ levels for six rats. (B) The levels of $\alpha$-subunit and $\mathrm{LH} \beta$-subunit mRNAs in pituitaries of testosterone-treated CAST rats were measured at various time points after treatment. The density of each band from autoradiograms of RNA blots was measured by scanning densitometry (see legend of Fig. 1). Representative bands are shown in Fig. 4. Each bar represents the mean density \pm SD of six pituitaries (except for the $0-h$ and 7-d points, which represent the mean density \pm SD of three pituitaries). Open bars correspond to bands representing RNAs hybridized to the $\alpha$-subunit DNA probe. Shaded bars correspond to bands representing RNAs hybridized to the LH $\beta$-subunit DNA probe. Stars indicate statistical significance of data points compared to control levels: $*, P<0.05$; and $* *, P<0.01$. 


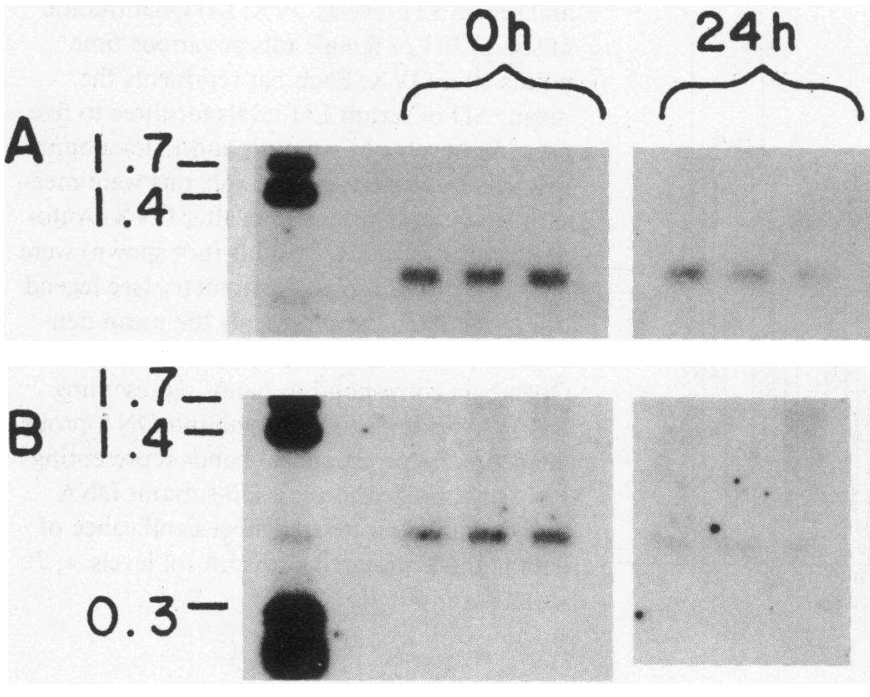

be made. However, a comparison of the changes in the ratios of the two subunit mRNAs from an arbitrary standardized control value are interpretable (Fig. $4 \mathrm{~B}$ ). Table I reveals that despite the fact that both $\alpha$ - and LH $\beta$-subunit mRNA levels declined simultaneously, at 24 and $48 \mathrm{~h}$ after testosterone treatment of CAST rats, the $\alpha / \mathrm{LH} \beta$ subunit mRNA ratio increased, which indicates that the $\mathrm{LH} \beta$-subunit mRNA levels declined to a greater degree than did the $\alpha$-subunit mRNA levels.

Females. The serum LH levels in OVX rats also declined rapidly with estradiol treatment. Mean serum $\mathrm{LH}$ declined from $11.1 \pm 2.6 \mathrm{ng} / \mathrm{ml}$ in control $(0 \mathrm{~h})$ animals to $36 \%$ of control levels $(4.0 \pm 1.3 \mathrm{ng} / \mathrm{ml})$ at $48 \mathrm{~h}(P<0.01)$ and to $10 \%$ of control levels $(1.1 \mathrm{ng} / \mathrm{ml})$ at $7 \mathrm{~d}$ after injections were initiated (Fig. $6 \mathrm{~A}$ ).

The decrease in pituitary LH subunit mRNA levels in estradiol-treated OVX rats followed a pattern similar to that seen in the male rats. The mean $\alpha$-subunit mRNA level decreased from control levels of $100 \pm 54.0 \mathrm{ADU}$ to 26.0 $\pm 6.7 \mathrm{ADU}$, or $26 \%$ of control levels at $24 \mathrm{~h}(P<0.05)$, to $19.0 \pm 6.7 \mathrm{ADU}$ or $19 \%$ of control levels at $48 \mathrm{~h}(P<0.01)$, and $17.0 \mathrm{ADU}$ or $17 \%$ of control levels at $7 \mathrm{~d}\left(\mathrm{t}_{1 / 2}=22 \mathrm{~h}\right)$. As in the testosterone-treated CAST rats, the mean $\mathrm{LH} \beta$-subunit mRNA level in the estradioltreated OVX rats also declined more rapidly than did the mean $\alpha$-subunit mRNA level. The mean $\mathrm{LH} \beta$-subunit mRNA was decreased from $100 \pm 38.0$ ADU to $18.0 \pm 19.0$ ADU or $18 \%$ of

Table I. $\alpha / L H \beta^{*}$ mRNA Levels in Gonadal-steroid-hormone-treated Rats

\begin{tabular}{rcc}
\hline Time & Male & Female \\
\hline $0 \mathrm{~h}$ & 1.00 & 1.00 \\
$24 \mathrm{~h}$ & 2.3 & 1.89 \\
$48 \mathrm{~h}$ & 4.3 & 1.90 \\
$7 \mathrm{~d}$ & 10.0 & $>10.0$
\end{tabular}

\footnotetext{
* Ratios are calculated from the values for $\alpha$ - and LH $\beta$-subunit mRNA levels that are represented in Figs. $4 B$ and $6 B$. Values are normalized such that the $\alpha / \mathrm{LH} \beta$ mRNA at $0 \mathrm{~h}$ is 1.0 . Mature rats were injected with testosterone propionate or $17 \beta$-estradiol-3-benzoate daily (as described in Methods), and killed at various time points ( 0 , $12,24,48 \mathrm{~h}$, and $7 \mathrm{~d}$ ) after injections were initiated.
}

Figure 5. RNA blot hybridization analysis. Testosteronetreated CAST rats. Synthetic oligodeoxyribonucleotide probes corresponding to cDNAs specific for $(A)$ rat $\alpha$-subunits and $(B)$ LH $\beta$-subunits were hybridized to total cellular RNA from the pituitaries of CAST rats at various time points after testosterone injections were initiated. Each lane contains $5 \mu \mathrm{g}$ of RNA from a single pituitary gland. The same blot was used for both hybridizations. Representative bands are shown. Exposure time was $24 \mathrm{~h}$ for $(A)$ and $72 \mathrm{~h}$ for $(B)$ using XAR film (Eastman Kodak Co.) and an intensification screen. Size markers (in $\mathrm{kb}$ ) are shown at left.

control levels at $24 \mathrm{~h}(P<0.05)$, to $10.0 \pm 5.5$ ADU or $10 \%$ of control levels at $48 \mathrm{~h}(P<0.01)$, and to undetectable levels at $7 \mathrm{~d}\left(\mathrm{t}_{1 / 2}=13 \mathrm{~h}\right)$. Although the mean values of both $\alpha$ - and LH $\beta$ subunit mRNA levels at $12 \mathrm{~h}$ were greater than control values, these elevations are not statistically significant (Fig. $6 \mathrm{~B}$ ).

The ratio of pituitary $\alpha$-subunit to $\mathrm{LH} \beta$-subunit mRNA levels also increased with time after initiation of estradiol-treatment in OVX rats (Table I). These data show that the $\alpha$-subunit mRNA levels declined to a lesser degree than did the LH $\beta$-subunit with estradiol treatment levels in these animals.

\section{Discussion}

GDX rats offer an excellent system in which to study regulation of the LH subunit genes, because of the high levels of LH production as manifested by marked elevation of serum levels and pituitary content of LH in these animals, and because these parameters can be suppressed by treatment with gonadal-steroid hormones.

Many studies have shown that GDX increases serum concentrations $(7,9-13,17,20,25,36-38)$ and pituitary content of gonadotropins $(9,10,25)$. The increase in serum $\mathrm{LH}$ concentration occurs rapidly, and peak levels, four- to 20-fold higher than control values, are achieved $\sim 3$ wk after castration $(20$, 25). In this study, peak serum LH levels were ninefold and 20 fold increased above control levels, $31 \mathrm{~d}$ after GDX, in males and females, respectively.

Several studies have shown, using cell-free translation $(9,18)$ and microsomal run-off techniques (19), a four- to 15-fold increase in the levels of both $\alpha$ - and LH $\beta$-subunit mRNAs in pituitaries of GDX animals. Corbani et al. (20) observed a slightly greater rise in translatable $\mathrm{LH} \beta$-subunit than in $\alpha$-subunit mRNA activity levels in both male and female rats $21 \mathrm{~d}$ postgonadectomy. Our results confirm these data. In our study, peak subunit mRNA levels were also reached $3 \mathrm{wk}$ postgonadectomy with six- and ninefold increases above control levels observed in $\alpha$ subunit with mRNA and eight- and 15-fold increases above control levels observed in $\mathrm{LH} \beta$-subunit mRNA levels for males and females, respectively. The greater increase in $\mathrm{LH} \beta$-subunit mRNA levels in OVX rats paralleled the rise in serum LH levels in the same animals. 

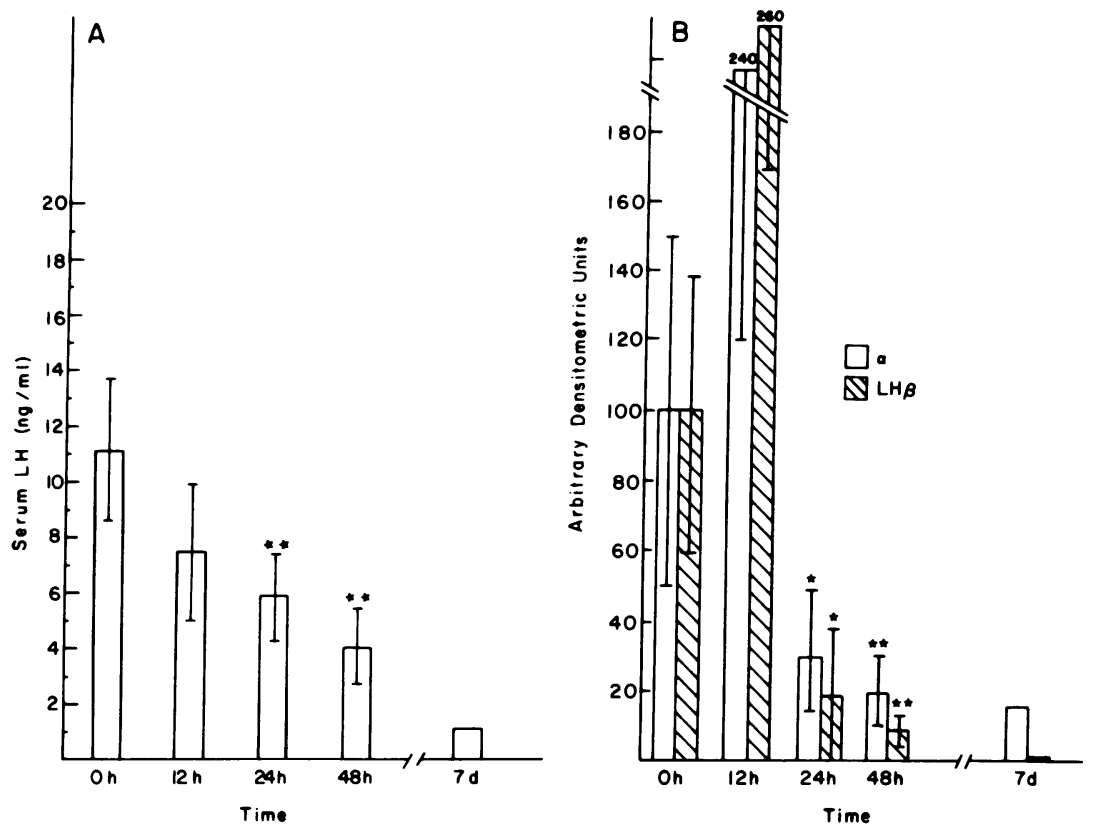

Figure 6. Serum LH levels and pituitary LH subunit mRNA levels. Estrogen-treated OVX rats: $(A)$ Serum LH levels of OVX rats were measured at different time points after treatment with estradiol benzoate. Each bar represents the mean \pm SD of serum LH levels for six rats. $(B)$ The subunit levels of $\alpha$-subunit and LH $\beta$-subunit mRNAs in pituitaries of estrogen-treated OVX rats were measured at various time points after treatment. The density of each band from autoradiograms of RNA blots (not shown) was measured with a scanning densitometer. Each bar represents the mean density \pm SD of six bands for each time point (except the 0 -h point, which represents the mean density \pm SD of three bands, and the 7-d point, which represents the density of a single band). The open bars correspond to the bands representing RNAs hybridized to the $\alpha$-subunit DNA probe. Shaded bars correspond to bands representing RNAs hybridized to the LH $\beta$-subunit DNA probe. Stars indicate statistical significance of data points compared with control levels: *, $P<0.05$; and **, $P<0.01$.

In GDX male and female rats, the rise in serum LH preceded the rise in subunit mRNAs in this study. This finding agrees with the data of other investigators (20). It is known that after CAST of adult male rats, a decline in pituitary LH content occurs concomitantly with an immediate rise in serum $\mathrm{LH}$ within the first day (10). This is followed by a gradual rise in pituitary LH content to levels approximately fourfold higher than control levels $(10,25)$. In addition, GnRH receptors are known to increase as early as $24 \mathrm{~h}$ after GDX $(10,11)$. Thus, release of preexisting LH may account for the initial rise in serum $\mathrm{LH}$, while increased subunit mRNA levels may be responsible for the increase in serum LH seen at later time points after GDX.

The rise in subunit mRNA levels with time after castration may result from either an increase in the number of transcripts or an increase in RNA stability. A third possibility is that the percentage of gonadotrope cells within the pituitary cell population increases with time after castration. Changes in the gonadotrope cell population have been studied (Gwen Childs, personal communication). It has been determined that while gonadotrope cells represent $10 \%$ of all cells in the pituitaries of intact animals, they represent $18 \%$ of pituitary cells of ovariectomized animals. Therefore, because LH subunit mRNA levels increased six- to 7.5-fold in the male rats and 10- to 15-fold in the female rats after gonadectomy, while the increase in gonadotrope cells in the same period of time was at most twofold, changes in gonadotrope cell populations alone cannot account for the increases in subunit mRNA levels seen in this study.

It has long been established that gonadal-steroid hormones regulate gonadotropin secretion (39). The mechanism of this negative feedback remains unclear. It has been shown that treatment of castrated rats with gonadal-steroid hormones lowers plasma LH levels $(6-9,12,13)$. In the present study, serum LH levels declined to 8 and $38 \%$ of control levels within $48 \mathrm{~h}$ of initiation of gonadal-steroid hormone treatment in males and females, respectively. In addition, cell-free translation studies have shown that both pituitary $\alpha$-subunit (17) and LH $\beta$-subunit (21) mRNA activity levels are lower in gonadal-steroid hormonetreated OVX ewes than in untreated GDX controls (7). Using blot hybridization analyses, others have also shown that treatment of OVX ewes with estradiol results in a dramatic reduction in steady state $\alpha$-subunit and LH $\beta$-subunit mRNA levels (8).

It has been suggested that synthesis of the $\beta$-subunit is the rate-determining step in the biosynthesis of mature glycoprotein hormones (16-19). This hypothesis was based upon the repeated observation that serum and intracellular levels of pituitary and placental free $\alpha$-subunit exceed the serum and intracellular levels of intact glycoprotein hormones $(14,15,40,41)$. In addition, in cell-free translation studies $(13,21)$ and blot hybridization studies (42), $\alpha$-subunit mRNA levels exceed LH $\beta$ - and TSH $\beta$ subunit mRNA levels in various physiologic situations.

However, it is now known that $\alpha$-subunit biosynthesis is also regulated by gonadal-steroid hormones $(7-9,21)$ and by thyroid hormone (43-45). In general, in both these systems, it has been observed that the negative regulation of $\alpha$-subunit is less marked than is that of the $\beta$-subunit. Treatment of OVX ewes for 3 wk results in a $98 \%$ reduction in steady state pituitary $\mathrm{LH} \beta$-subunit mRNA levels but only an $86 \%$ reduction in steady-state $\alpha$-subunit mRNA levels (8). TSH $\beta$-subunit mRNA levels in hypothyroid rat pituitaries are undetectable after $4 \mathrm{~d}$ of thyroid hormone treatment, while $\alpha$-subunit mRNA levels are reduced, but still detectable (43). Similarly, Chin et al. (45) have found that treatment of hypothyroid mice bearing thyrotropic tumor for $33 \mathrm{~d}$ with thyroid hormone results in undetectable ( $<1 \%$ of control) levels of TSH $\beta$-subunit mRNA levels, but measurable $\alpha$ subunit levels that were $6 \%$ of control levels. By contrast, Gurr et al. (46) found no change in $\alpha$-subunit mRNA levels, whereas $\operatorname{TSH} \beta$-subunit levels declined to $10 \%$ of control levels after 10 d of treatment with thyroid hormone.

Our data are in agreement with these findings. There was a 94\% reduction in $\mathrm{LH} \beta$-subunit mRNA levels but only a $74 \%$ reduction in $\alpha$-subunit mRNA levels in testosterone-treated CAST males $48 \mathrm{~h}$ after treatment. In the estradiol-treated OVX rats, there were 90 and $81 \%$ reductions in $\mathrm{LH} \beta$-subunit mRNA levels and $\alpha$-subunit in the same time period. Even after $7 \mathrm{~d}$ of gonadal-steroid hormone treatment, $\alpha$-subunit levels were $\mathbf{1 2 . 0}$ and $17.0 \%$ of control levels in males and females, respectively, 
while $\mathrm{LH} \beta$-subunit levels were barely detectable. These data suggest that although both $\alpha$ - and $\mathrm{LH} \beta$-subunit mRNAs are negatively regulated by gonadal steroid hormones, $\mathrm{LH} \beta$-subunit mRNAs are more sensitive to this negative feedback effect than are $\alpha$-subunit mRNAs.

The precise mechanism of the regulation of $\alpha$-subunit genes and $\mathrm{LH} \beta$-subunit genes by gonadal steroid hormones remains unclear. The possibilities include $(a)$ a decrease in the number of transcripts, or $(b)$ increased RNA instability. Steroid hormones are known to modulate mRNA levels by both mechanisms in a multitude of systems. For instance, estrogen increases the rate of transcription of ovalbumin (47), vitellogenin (48), transferrin (49), and prolactin (50) genes. On the other hand, estrogen and progesterone are known to increase substantially the half-lives of ovalbumin and conalbumin mRNAs (51), and estrogen stabilizes Xenopus liver vitellogenin mRNA, resulting in large increases in its steady state level (52). In addition, glycoprotein subunit mRNA levels can also be affected by other hormones. Shupnik et al. (53) have shown that thyroid hormone rapidly decreases the rates of transcription of both the $\alpha$ - and TSH $\beta$ subunit genes. Whether gonadal-steroid hormones have similar effects on either the transcriptional rates or half-lives of $\alpha$ - and LH $\beta$-subunit mRNAs is not known. Transcriptional studies are in progress to clarify this point.

In summary, we have described the time course of the rise in the steady-state $\alpha$-subunit and $\mathrm{LH} \beta$-subunit mRNA levels after GDX in both male and female rats, which roughly parallels the increase in serum LH. In addition, we have shown that gonadal-steroid hormones negatively regulate the steady state $\alpha$ subunit and LH $\beta$-subunit mRNA levels in GDX male and female rats but that the $\mathrm{LH} \beta$-subunit mRNA levels are regulated to a greater degree than are $\alpha$-subunit mRNA levels. The decline in serum $\mathrm{LH}$ is rapid, and parallels the decline in $\mathrm{LH} \beta$-subunit mRNA levels.

We conclude that the gonadal sex steroid hormones affect the synthesis of LH at the pretranslational level by influencing the steady state levels of subunit mRNAs. Transcriptional studies are currently under way in this laboratory to determine whether these effects occur at the transcriptional or RNA stability levels.

\section{Acknowledgments}

We thank Nancy Patterson for her careful preparation of this manuscript. We also thank Gary Gryan and Chon Vo for their assistance in the synthesis of the oligodeoxyribonucleotides, and Maureen F. Downing for her assistance with the LH RIA. We are also indebted to Dr. E. Francis Cook and Dr. David Kieffer for their helpful advice in the statistical interpretation of these data. The critical reading of this manuscript by Dr. E. Chester Ridgway was extremely beneficial. Finally, the helpful discussions and support of Dr. Joel F. Habener through the course of these experiments were deeply appreciated.

This work was funded in part by National Institutes of Health grant AM 25532.

\section{References}

1. Pierce, J. G., and T. F. Parsons. 1981. Glycoprotein hormones: structure and function. Annu. Rev. Biochem. 50:465-495.

2. Fiddes, J. C., and H. M. Goodman. 1981. The gene encoding the common alpha subunit of the four human glycoprotein hormones. $J$. Mol. Appl. Genet. 1:3-18.

3. Boothby, M., R. W. Ruddon, C. Anderson, D. McWilliams, and I. Boime. 1981. A single gonadotropin $\alpha$-subunit gene in normal tissue and tumor derived cell lines. J. Biol. Chem. 256:5121-5127.
4. Talmadge, K., W. R. Boorstein, and J. C. Fiddes. 1983. The human genome contains seven genes for the $\beta$-subunit of chorionic gonadotropin but only one gene for the $\beta$-subunit of luteinizing hormone. DNA. (NY). 2:281-289.

5. Naylor, S. L., W. W. Chin, H. M. Goodman, P. A. Lalley, K. H. Grzeschik, and A. Y. Sakaguchi. 1983. Chromosome assignment of genes encoding the $\alpha$ and $\beta$ subunits of glycoprotein hormone in man and mouse. Somatic Cell. Genet. 9:757-770.

6. Gay, V. L., and E. M. Bogdanove. 1969. Plasma and pituitary LH and FSH in the castrated rat following short-term steroid treatment. Endocrinology. 84:1132-1142.

7. Landefeld, T. D., J. Kepa, and F. J. Karsch. 1983. Regulation of $\alpha$ subunit synthesis by gonadal steroid feedback in the sheep anterior pituitary. J. Biol. Chem. 258:2390-2393.

8. Nilson, J. H., M. T. Nejedlik, J. B. Virgin, M. E. Crowder, and T. M. Nett. 1983. Expression of $\alpha$ subunit and luteinizing hormone $\beta$ genes in the ovine anterior pituitary. Estradiol suppresses accumulation of mRNAs for both $\alpha$ subunit and luteinizing hormone $\beta$. J. Biol. Chem. 258:12087-12090.

9. Landefeld, T., J. Kepa, and F. Karsch. 1984. Estradiol feedback effects on the $\alpha$-subunit mRNA in the sheep pituitary gland: correlation with serum and pituitary luteinizing hormone concentrations. Proc. Natl. Acad. Sci. USA. 81:1322-1326.

10. Clayton, R. N., and K. J. Catt. 1981. Regulation of pituitary gonadotropin-releasing hormone receptors by gonadal hormones. Endocrinology. 108:887-895.

11. Frager, M. S., D. R. Pieper, S. A. Tonetta, J. A. Duncan, and J. C. Marshall. 1981. Pituitary gonadotropin-releasing hormone receptors. Effects of castration, steroid replacement, and the role of gonadotropinreleasing hormone in modulating receptors in the rat. J. Clin. Invest. 67: 615-623.

12. Schanbacher, B. D., and J. J. Ford. 1977. Gonadotropin secretion in cryptorchid and castrate rams and the acute effects of exogenous steroid treatment. Endocrinology. 100:387-393.

13. Rabii, J., and W. F. Ganong. 1976. Responses of plasma 'estradiol' and plasma LH to ovariectomy, ovariectomy plus adrenalectomy, and estrogen injection at various ages. Neuroendocrinology. 20:270-281.

14. Kaplan, S. L., M. M. Grumbach, and M. L. Aubert. 1976. $\alpha$ and $\beta$ glycoprotein hormone subunits (hLH, hFSH, hCG) in the serum and pituitary of the human fetus. J. Clin. Endocrinol. Metab. 42:995-998.

15. Kourides, I. A., M. B. Landon, B. J. Hoffman, and B. D. Weintraub. 1980. Excess free alpha relative to beta subunits of the glycoprotein hormones in normal and abnormal human pituitary glands. Clin. Endocrinol. 12:407-416.

16. Counis, R., G. Ribot, M. Corbani, M. Poissonnier, and M. Jutisz. 1981. Cell-free translation of the rat pituitary messenger RNA coding for the precursors of $\alpha$ and $\beta$ subunits of lutropin. FEBS (Fed. Eur. Biochem. Soc.) Lett. 123:151-155.

17. Godine, J. E., W. W. Chin, and J. F. Habener. 1980. Luteinizing and follicle-stimulating hormones. Cell-free translations of messenger RNAs coding for subunit precursors. J. Biol. Chem. 255:8780-8783.

18. Keller, D., J. Fetherston, and I. Boime. 1980. Isolation of mRNA from bovine pituitary. The cell-free synthesis of the $\alpha$ and $\beta$ subunits of luteinizing hormone. Eur. J. Biochem. 108:367-372.

19. Fetherston, J., and I. Boime. 1982. Synthesis of bovine lutropin in cell-free lysates containing pituitary microsomes. J. Biol. Chem. 257: 8143-8147.

20. Corbani, M., R. Counis, A. Starzec, and M. Jutisz. 1984. Effect of gonadectomy on pituitary levels of mRNA encoding gonadotropin subunits and secretion of luteinizing hormone. Mol. Cell. Endocr. 35: 83-87.

21. Counis, R., M. Corbani, and M. Jutisz. 1983. Estradiol regulates mRNAs encoding precursors to rat lutropin (LH) and follitropin (FSH) subunits. Biochem. Biophys. Res. Commun. 114:65-72.

22. Tepper, M. A., F. T. Dionne, J. H. Eberwine, J. N. Wilcox, and J. L. Roberts. 1984. Regulation of beta LH gene expression during the estrus cycle and castration in the rat. 7th International Congress of Endocrinology, Quebec City, Canada. Abstract No. 2293. 
23. Ross, D. S., M. F. Downing, W. W. Chin, and E. C. Ridgway. 1984. Discordant changes in pituitary concentrations of LH and TSH subunits following hormonal manipulation. Metabolism. 33:230-234.

24. Kieffer, J. D., H. Mover, P. Federico, and F. Maloof. 1976. Pituitary-thyroid axis in neonatal and adult rats. Endocrinology. 98:295304.

25. Badger, T. M., C. E. Wilcox, E. R. Meyer, R. D. Bell, and T. J. Cicero. 1978. Simultaneous changes in tissue and serum levels of luteinizing hormone, follicle-stimulating hormone, and luteinizing hormone/follicle-stimulating hormone releasing factor after castration in the male rat. Endocrinology. 102:136-141.

26. Godine, J. E., W. W. Chin, and J. F. Habener. 1982. $\alpha$ subunit of rat pituitary glycoprotein hormones. Primary structure of the precursor determined from the nucleotide sequence of cloned DNAs. J. Biol. Chem. 257:8368-8371.

27. Chin, W. W., J. E. Godine, D. R. Klein, A. S. Chang, L. K. Tan, and J. F. Habener. 1983. Nucleotide sequence of the cDNA encoding the precursor of the $\beta$ subunit of rat lutropin. Proc. Natl. Acad. Sci. USA. 80:4649-4653.

28. Maxam, A. M., and W. Gilbert. 1980. Sequencing end-labeled DNA with base-specific chemical cleavages. Methods Enzymol. 65:499_ 560.

29. Maniatis, T., A. Jeffrey, and D. G. Kleid. 1975. Nucleotide sequence of the rightward operator of Phage $\lambda$. Proc. Natl. Acad. Sci. USA. 72:1184-1188.

30. Chirgwin, J. M., A. E. Przybyla, R. J. MacDonald, and W. J. Rutter. 1979. Isolation of biologically active ribonucleic acid from sources enriched in ribnonuclease. Biochemistry. 18:5294-5299.

31. Thomas, P. S. 1980. Hybridization of denatured RNA and small DNA fragments transferred to nitrocellulose. Proc. Natl. Acad. Sci. USA. 77:5201-5205.

32. Nilson, J. H., A. R. Thomason, M. T. Cserbak, C. L. Moncman, and R. P. Woychik. 1983. Nucleotide sequence of a cDNA for the common $\alpha$ subunit of the bovine pituitary glycoprotein hormones. Conservation of nucleotides in the 3'-untranslated region of bovine and human pre- $\alpha$ subunit mRNAs. J. Biol. Chem. 258:4679-4682.

33. Hamlyn, P. H., and T. H. Rabbitts. 1983. Translocation joins c$m y c$ and immunoglobulin $\gamma 1$ genes in a Burkitt lymphoma revealing a third exon in the c-myc oncogene. Nature (Lond.). 304:135-139.

34. Snedecor, G. W., and W. G. Cochran. 1967. Statistical Methods. 6th ed. Iowa State University Press, Ames, IA.

35. Lehman, E. L. 1975. Nonparameterics: Statistical Methods Based On Ranks. Holden Day, Inc., Oakland, CA. 137.

36. Gay, V. L., and A. R. Midgley. 1969. Response of the adult rat to orchidectomy and ovariectomy as determined by LH radioimmunassay. Endocrinology. 84:1359-1364.

37. Butterstein, G. M., W. Friedman, M. C. Rehder, and F. Wilion.
1983. Release of luteinizing hormone in prepubertal and middle-aged ovariectomized rats. Proc. Soc. Exp. Biol. Med. 172:11-15.

38. Yamamoto, M., N. D. Diebel, and E. M. Bogdanove. 1970. Analysis of initial and delayed effects of orchidectomy and ovariectomy on pituitary and serum LH levels in adult and immature rats. Endocrinology. 86:1102-1111.

39. Schally, A. V., A. J. Kastin, and A. Arimura. 1972. FSH-releasing hormone and LH-releasing hormone. Vitam. Horm. 30:83-164.

40. Kourides, I. A., B. D. Weintraub, E. C. Ridgway, and F. Maloof. 1975. Pituitary secretion of free alpha and beta subunit of human thyrotropin in patients with thyroid disorders. J. Clin. Endocrinol. Metab. 40:872-885

41. Vaitukaitis, J. L. 1974. Changing placental concentrations of human chorionic gonadotropin and its subunits during gestation. J. Clin. Endocrinol. Metab. 38:755-760.

42. Gurr, J. A., and I. A. Kourides. 1984. Ratios of $\alpha$ to $\beta$ TSH mRNA in normal and hypothyroid pituitaries and TSH-secreting tumors. Endocrinology. 115:830-832.

43. Croyle, M. L., and R. A. Maurer. 1984. Thyroid hormone decreases thyrotropin subunit mRNA levels in rat anterior pituitary. DNA. (NY). 3:231-236.

44. Shupnik, M. A., W. W. Chin, D. S. Ross, M. F. Downing, J. F. Habener, and E. C. Ridgway. 1983. Regulation by thyroxine of the mRNA encoding the $\alpha$ subunit mouse thyrotropin. J. Biol. Chem. 258: 15120-15124.

45. Chin, W. W., M. A. Shupnik, D. S. Ross, J. F. Habener, and E. C. Ridgway. 1985. Regulation of the $\alpha$ and TSH $\beta$ subunit mRNAs by thyroid hormone. Endocrinology. 116:873-878.

46. Gurr, J. A., and I. A. Kourides. 1983. Regulation of thyrotropin biosynthesis. Discordant effect of thyroid hormone on $\alpha$ and $\beta$ subunit mRNA levels. J. Biol. Chem. 258:10208-10211.

47. Woo, S. L. C., and B. W. O'Malley. 1975. Hormone inducible messenger RNA. Life Sci. 17:1039-1048.

48. Baker, H. J., and D. J. Shapiro. 1978. Rapid accumulation of vitellogenin messenger RNA during secondary estrogen stimulation of Xenopus laevis. J. Biol. Chem. 253:4521-4524.

49. McKnight, G. S., D. C. Lee, and R. D. Palmiter. 1980. Transferrin gene expression. Regulation of mRNA transcription in chick liver by steroid hormones and iron deficiency. J. Biol. Chem. 255:148-153.

50. Maurer, R. A. 1982. Estradiol regulates the transcription of the prolactin gene. J. Biol. Chem. 257:2133-2136.

51. McKnight, G. S., and R. D. Palmiter. 1979. Transcriptional regulation of the ovalbumin and conalbumin genes by steroid hormones in chick oviduct. J. Biol. Chem. 254:9050-9058.

52. Brock, M. L., and D. J. Shapiro. 1983. Estrogen stabilizes vitellogenin mRNA against cytoplasmic degradation. Cell. 34:207-214.

53. Shupnik, M. A., W. W. Chin, J. F. Habener, and E. C. Ridgway. Transcriptional regulation of the thyrotropin subunit genes by thyroid hormones. J. Biol. Chem. 260:2900-2903. 